Al-Tanzim : Jurnal Manajemen Pendidikan Islam

\title{
DESAIN KURIKULUM SEKOLAH ISLAM TERPADU (Studi Kasus di SMPIT Insan Kamil Sidoarjo)
}

\author{
Mohamad Rojii*, Istikomah, Choirun Nisak Aulina, Imam Fauji \\ Universitas Muhammadiyah, Sidoarjo, Indonesia \\ *Email : mohamadrojii1993@gmail.com
}

DOI: http://doi.org/10.33650/al-tanzim.v3i2.667

\begin{tabular}{l|l|c|} 
Received: September 2019 & Revised: November 2019 & Approved: November 2019 \\
\hline
\end{tabular}

\begin{abstract}
:
Integrated Islamic School is a school whose curriculum integrates Islamic values, skills and national curriculum. The purpose of this research is to describe curriculum design in integrated Islamic schools by taking a research site at SMPIT Insan Kamil Sidoarjo. This research uses a qualitative approach with case study. The research data obtained from interviews, observations, and documentation, then analyzed by reducing data, presenting data, and making conclusions. The results showed that the curriculum design in SMPIT Insan Kamil Sidoarjo emphasized the internalization of Islamic values in every national curriculum content, without overriding the national curriculum set by the Ministry of Education. The assessment process is the main objective created in the learning environment and the content of teaching materials that are loaded with Islamic values. While the purpose of the curriculum design is, so that students have a strong foundation of religious education, which boils down to the strength of aqeedah and moral perfection. Internalization of Islamic values in integrated Islamic schools is not only done through the subjects taught, but through the design of school activities programs that support the inculcation of Islamic values in students.
\end{abstract}

Key words : Integrated Islamic School, Curriculum Design

\begin{abstract}
Abstrak
Sekolah Islam Terpadu merupakan sekolah yang kurikulumnya mengintegrasikan antara nilainilai Islam, keterampilan dengan kurikulum nasional. Tujuan penelitian ini adalah untuk mendiskripsikan tentang desain kurikulum di sekolah Islam terpadu dengan mengambil situs penelitian di SMPIT Insan Kamil Sidoarjo. Penelitian ini menggunakan pendekatan kualitatif jenis studi kasus. Data penelitian didapat dari hasil wawancara, observasi, dan dokumentasi, kemudian di analisa dengan mereduksi data, menyajikan data, dan membuat kesimpulan. Hasil penelitian menunjukkan bahwa desain kurikulum yang ada di SMPIT Insan Kamil Sidoarjo lebih menekankan pada internalisasi nilai-nilai Islam dalam setiap muatan kurikulum nasional, tanpa mengenyampingkan kurikulum nasional yang telah ditetapkan oleh kementrian pendidikan. Penilaian proses merupakan tujuan utama yang tercipta dalam lingkungan belajar maupun konten bahan ajar yang sarat dengan nilai-nilai Islam. Sedangkan tujuan dari desain kurikulumnya adalah, agar peserta didik memiliki landasan pendidikan agama yang kuat, yang bermuara pada kekuatan aqidah dan kesempurnaan akhlak. Internalisasi nilai-nilai keIslaman pada sekolah Islam terpadu bukan hanya dilakukan melalui mata pelajaran yang diajarkan, akan tetapi melalui desain program kegiatan sekolah yang mendukung dalam penanaman nilai-nilai Islam pada peserta didik.
\end{abstract}

Kata Kunci : Sekolah Islam Terpadu, Desain Kurikulum 


\section{PENDAHULUAN}

Lembaga pendidikan di Indonesia sangat beragam, di antaranya ada pesantren, madrasah dan sekolah. Sekolah sebagai lembaga pendidikan formal yang pertama di akui oleh pemerintah dan didirikan oleh Belanda di abad ke 21 telah mengalami perkembangan, baik ditinjau dari coraknya maupun sifat lembaganya. Perkembangan-perkembangan tersebut selalu di hadapkan pada sebuah tantangan, sedangkan tantangan terbesar yang sedang di hadapi oleh pendidikan nasional saat ini adalah bagaimana bisa memberikan pelayanan berupa pendidikan yang berkualitas dan dapat diakses oleh seluruh lapisan masyarakat, pedidikan yang berkualitas akan menghasilakan manusia Indonesia yang berkualitas pula, sehingga dengan banyaknya rakyat Indonesia yang mengenyam pendidikan yang berkualitas akan meningkatkan secara signifikan kualitas dari bangsa Indonesia pula (Fatkuroji, 2012).

Seiring usaha perkembangan tersebut, pastinya terdapat banyak kritik pada sistem pendidikan di Indonesia, salah satu kritikan yang paling dipersoalkan adalah tentang muatan kurikulum, ketidakpuasan tersebut ditujukan terhadap sistem pendidikan nasional (sekolah) di bawah naungan kementerian Pendidikan Nasional yang muatan kurikulumnya lebih menekankan pada aspek kognitif dan lemah pada aspek-aspek yang lainnya (Suparno, 2018). Sedangkan para orang tua di Indonesia, yang mayoritas beragama Islam membutuhkan model pendidikan yang lebih memperhatikan aspek religius pada peserta didiknya. Dalam ajaran Islam juga telah dinyatakan bahwa pendidikan haruslah mencakup segala aspek yang dibutuhkan oleh manusia untuk kehidupan dunia dan akhiratnya. Pendidikan Islam merupkan kesatuan dari sebuah proses spiritual, sosial, akhlak, dan intelektual yang senantiasa memberikan nilai-nilai, prinsip serta teladan ideal dalam kehidupan, dan bertujuan untuk mempersiapkan kebahagiaan di dunia dan akhirat (Susanto, 2010).

Melihat idealitas pendidikan Islam di atas, setidaknya problem terbesar pendidikan Islam saat ini dalam menghadapi tantangan kehidupan modern dapat di bagi menjadi tiga perkara, yaitu masalah dikotomi, atau pemisahan keilmuan agama dan umum, kedua, tujuan dan fungsi lembaga pendidikan Islam, dan yang ketiga, adalah persoalan kurikulum dan materi pelajaran (Tajab, 2014).

Berangkat dari kegelisahan di atas, pada akhirnya para aktivis ini beruapaya untuk dapat mendirikan sebuah lembaga pendidikan yang di idamidamkan masyarakat muslim saat ini, yaitu lembaga pendidikan modern yang tidak lagi memisahkan antara pengajaran ilmu-ilmu umum dan ilmu-ilmu agama, mereka berharap lembaga pendidikan yang mereka dirikan nantinya akan dapat di terima dan menjadi bagian dari sistem pendidikan nasional, hasil pemikiran dan kerja keras para aktivis Islam tesebutlah yang pada akhirnya menjadi cikal akan dan akar sejarah kemunculan model pendidikan Islam terpadu di Indonesia. Para penggagas awal sekolah Islam terpadu 
Al-Tanzim : Jurnal Manajemen Pendidikan Islam E-ISSN: 2549-5720 P-ISSN: 2549-3663

Vol. 03 No. 02 (2019) : 49-60

https:// ejoumal.unija.ac.id/ index.php/al-tanzim

berpandangan bahwa dualisme sistem pendidikan di Indonesia harus segera dihapuskan, dan harapan mereka ada pada bentuk sekolah baru yang mereka gagas tersebut, mereka ingin nantinya setiap siswa yang telah menyelesaikan program pendidikan di Indonesia tidak hanya menguasai salah satu keilmuan saja, antara ilmu umum atau ilmu agama, akan tetapi mereka akan lulus dengan memiliki kompetensi di bidang keilmuan umum dan diperkuat dengan pemahaman serta praktik beragama yang sangat baik (Suyatno, 2013).

Jika menelisik lebih jauh tentang hakikat dari sekolah Islam terpadu, dapat dipahami bahwa sekolah Islam terpadu merupakan sebuah lembaga pendidikan dengan konsep yang baru yang dikelola oleh sekelompok masyarakat di mana dalam pengelolaannya dipadukan antara beberapa aspek, yaitu kurikulum, pembelajaran, tenaga pendidik, sarana dan prasarana, manajemen dan evaluasi (R. Syarifudin, 2004).

Sekolah Islam terpadu merupakan sekolah yang bangunan kerangka kurikulumnya mencoba untuk memadukan secara maksimal antara keilmuan agama dan keilmuan umum, keterpaduan ini secara gamblang dapat diaplikasikan dalam proses pembelajaran di kelas, yang senantiasa mencoba untuk memasukkan nilai-nilai luhur Islam dalam setiap mata pelajaran dengan cara dan model pembelajaran yang inovatif (Usman, 2008). Terdapat beberapa konsep terpadu, yang pertama, keterpaduan antara pendidik di sekolah dan orang tua siswa dalam melaksanakan proses pendidikan, kedua, keterpaduan dalam kurikulumnya, di mana dipadukan antara kurikulum nasional, kurikulum khusus Islam terpadu dan kurikulum lembaga, ketiga, keterpaduan antara seluruh stakeholder.

Sekolah Islam terpadu yang muncul pada era sekarang ini hadir untuk menjawab tantangan pendidikan yang tengah dihadapi masyarakat. Tentunya lembaga tersebut memiliki rancangan program pendidikan yang akan dijalankan. Rancangan program pendidikan pada setiap jenjang yang akan digunakan sebagai pijakan pelaksanaan pendidikan disebut dengan istilah kurikulum. Kurikulum merupakan alat yang di gunakan sebagai dasar acuan dalam usaha mencapai tujuan pendidikan yang telah ditetapkan (Sholihah, 2017). Berdasarkan latar belakang di atas, maka perlu dilakukan kajian lebih mendalam tentang desain kurikulum seperti apakah yang telah di tetapkan oleh JSIT (Jaringan Sekolah Islam Terpadu) untuk merealisasikan tujuan sebagai lembaga yang akan memberikan pelayanan pendidikan umum dan pendidikan agama secara seimbang kepada peserta didik. Maka dari itu, peneliti melakukan kajian khusus terhadap desain kurikulum sekolah Islam terpadu, yang secara khusus penulis memilih melakukan penelitian di SMP Islam terpadu Insan Kamil Sidoarjo. 


\section{Hakikat dan Urgensi Kurikulum}

Kurikulum merupakan salah satu dari komponen pendidikan yang sangat menentukan berhasil atau tidaknya program pendidikan yang telah direncanakan oleh pembuat kebijakan. Secara bahasa kurikulum merupakan sebuah kata yang lahir dari dunia atletik, yaitu curir atau courier, yang maknanya to run, berlari, atau juga bisa diartikan dengan jarak yang harus ditempuh oleh seorang atlit lari, dari garis start hingga garis finish. Istilah ini kemudian dibawa pada dunia pendidikan dan menjadikan maknanya berubah menjadi suatu pelajaran atau materi yang harus diambil seorang pelajar untuk mendapatkan pengakuan atau penghargaan dari proses pendidikannya (Offorma, 2016)

Kurikulum menurut pandangan lama memang hanya sebatas mata pelajaran yang harus ditempuh oleh seorang pelajar untuk dapat lulus dan mendapatkan ijazah. Akan tetapi, dalam pandangan modern, arti dari kurikulum tidak hanya sebatas itu. Makna kurikulum dalam pandangan modern adalah keseluruhan pengalaman belajar siswa selama mereka berada di sekolah. Ketika seorang anak mendaftar ke sekolah, maka dia telah mendaftar untuk segera memulai belajarnya (perlombaanya), dan dalam perlombaan nanti memungkinkan siswa untuk mendapatkan banyak pengalaman yang nyata dari proses belajarnya. Pengalaman tersebut dapat berupa pengalaman intelektual, sosial, moral, spiritual dan fisik (Hanun Asrohah, 2013)

Kurikulum dapat di tinjau dari empat pilar berikut; Pertama, kurikulum dapat dilihat sebagai hasil karya para pengembang kurikulum yang berupa produk. Kedua, kurikulum dapat dipandang pula sebagai program, program disini digunakan sebagai alat yang dilakukan oleh sekolah atau madrasah untuk acuan dalam usaha mencapai tujuannya. Ketiga, kurikulum dipandang sebagai sesuatu yang diharapkan akan dipelajari oleh peserta didik yang mencakup pengetahuan, sikap dan keterampilan. Keempat, kurikulum sebagai pengalaman peserta didik. Pandangan ini melihat pada apa yang lebih faktual dari kenyataan apa yang di alami oleh peserta didik, meskipun terkadang itu berbeda dengan apa yang direncanakan (Cullinan, 2016).

Kurikulum menjadi sangat penting karena di dalamnya berisi deskripsi yang luas tentang tujuan pendidikan secara keseluruhan, sebuah kurikulum juga dapat mempengaruhi kebudayaan, trend nasional dan trend perpolitikan pada sebuah Negara. Dengan demikian, kurikulum berperan sebagai payung yang mencakup tujuan pendidikan yang didesain oleh negara (Suyatno, 2015). Kurikulum merupakan keseluruhan dari pengalaman belajar yang nyata bagi setiap peserta didik, di mana pengalaman tersebut membantunya untuk terus berkembang demi menentukan acuan arah kehidupannya untuk menjadi manusia yang produktif di masa yang akan dating. Kurikulum merupakan seperangkat komponen dalam pendidikan (tujuan, isi, strategi, evaluasi) yang diaplikasikan kepada peserta didik untuk mempersiapkan mereka agar dapat hidup dengan baik di tengah-tengah masyarakat. 
Al-Tanzim : Jurnal Manajemen Pendidikan Islam

E-ISSN: 2549-5720 P-ISSN: 2549-3663

Vol. 03 No. 02 (2019) : 49-60

https:/ / ejournal.unuja.ac.id/index.php/al-tanzim

\section{Karakteristik Sekolah Islam Terpadu}

Sekolah Islam Terpadu memiliki dasar dari kata terpadu itu sendiri. Terpadu merupakan simbol utama yang digunakan oleh sekolah. Terpadu memiliki arti adanya integrasi antara ilmu umum serta ilmu agama. Sekolah Islam Terpadu menganggap bahwa seluruh mata pelajaran sejatinya tidak dapat terlepas dari agama, karena agama memiliki tujuan akhir yaitu menjadikan siswa untuk bertauhid (Afrizal, 2011).

Penggunaan kata terpadu merupakan sebuah usaha untuk memunculkan sebuah konsep yang digunakan untuk membangun citra sekolah Islam Terpadu, yaitu sebuah citra bahwa, selain mempelajari serta mengembangkan sains dan teknologi, di sekolah ini juga dituntut untuk melakukan pembelajaran dan pengembangan pendidikan agama secara utuh. Kata terpadu menjadi sebuah dasar sekolah yang dijadikan simbol adanya keterpaduan antara pengembangan sains dan teknologi dengan ilmu-ilmu keIslaman.

Pendidikan dalam Sekolah Islam Terpadu memiliki tujuan umum yaitu, melakukan pembinaan kepada peserta didiknya agar menjadi insan yang bertakwa, yang tidak hanya cerdas namun juga berakhlak mulia, serta memiliki keterampilan yang memberi maslahat bagi umat manusia (Suyatno, 2015).

Dengan lahirnya konsep terpadu sebagai ilmu, dan pengembangan karakter siswa dengan berlandaskan ajaran Islam, pada akhirnya juga melahirkan sebuah harapan baru, bahwa peserta didik tidak hanya menguasai ilmu-ilmu ke-Islaman, akan tetapi ajaran Islam menjadi dasar berperilaku setiap peserta didik dalam kehidupan sehari-hari. Sedangkan kurikulum yang telah didesain oleh jaringan sekolah Islam Terpadu telah dapat melakukan Islamisasi proses pembelajaran di dalam kelas yg memiliki tujuan untuk membentuk kesadaran dan pola berfikir yang Islami (JSIT, 2006).

Karakteristik utama dari pendidikan Islam terpadu adalah sebagai berikut : Pertama, Islam memadai landasan filosofisnya. Kedua, bangunan kurikulum yang reintegrasi dengan keIslaman. Ketiga, menerapkan dan mengembangkan pola pembelajaran terpadu. Keempat, menjadikan percontohan perilaku yang baik dari guru sebagai sarana pendidikan akhlak. Kelima, menciptakan lingkungan pendidikan yang Islami jauh dari segala macam kemaksiatan. Keenam, dalam usaha pencapaian tujuan pendidikannya selalu melibatkan orang tua dan masyarakat. Ketujuh, mengedepankan ukhuwah Islamiyah dalam segala bentuk interaksi dengan warga sekolah. Kedelapan, membangun budaya, rawat, resik, runut, rapi sehat dan asri. Kesembilan, segala proses pendidikan didasarkan pada penjaminan mutu. Kesepuluh meningkatkan budaya profesionalisme (Afrizal, 2011).

Sekolah Islam terpadu memiliki karakteristik yang berbeda dengan sekolah ataupun madrasah pada umumnya, sekolah Islam terpadu mencoba memperkuat nilai-nilai Islam pada istilah terpadu itu sendiri, penguatan ini berupa Islamisasi pada segala aspek aktivitas pendidikan selama berada di 
sekolah, mulai dari pembiasaan, ekstra kurikuler dan segala bentuk pembelajaran di kelas yang lainnya. Sekolah Islam terpadu juga memiliki jalinan kurikulum hasil dari penyatuan pendidikan umum dan pendidikan agama, di mana selama ini dikotomi kurikulum tersebut menjadi masalah yang utama bagi pendidikan Islam di Indonesia. Sekolah Islam terpadu senantiasa mencoba untuk mengimplementasikan konsep pendidikan dengan berdasarkan kepada dua sumber utama ajaran Islam yaitu al-Qur'an dan al-Hadits. Dua sumber tersebutlah yang menjadi pedoman dalam penananaman nilai Islam, penguatan materi keIslaman, serta pembinaan dalam berakhlakul karimah (Sugiyono, 2010).

Sekolah Islam Terpadu merupakan sebuah lembaga pendidikan yang mengintegrasikan dua bentuk pendidikan yang selama ini dipisahkan yaitu antara pendidikan Islam dan pendidikan umum. Kedua bentuk pendidikan tersebut di satukan dalam sebuah kerangka kurikulum khas jaringan sekolah Islam terpadu, kurikululum yang telah padu tersebut bertujuan untuk membina karakter atau akhlakul karimah siswa dan kompetensi, serta keterampilan siswa.

\section{METODE PENELITIAN}

Penelitian ini mengunakan pendekatan kualitatif yang bersifat deskriptif analisis dengan pendekatan studi kasus. Lokasi penelitian di SMP Islam Terpadu Insan Kamil Sidoarjo. Subjek penelitian adalah kepala sekolah, para wakil dan guru. Sedangkan tekhnik pengumpulan datanya menggunakan wawancara, observasi, dan dokumentasi.

Dalam penelitian ini, data dianalisis menggunakan teknis analisis data yang telah di kembangkan oleh Miles and Huberman, maka dalam penelitian ini, data dianalisis secara interaktif dan secara terus menerus hingga mendapatkan data secara tuntas, untuk menjawab permasalahan dalam penelitian. Tahapan analisis datanya yaitu; data reduction atau reduksi data, data display atau penyajian data, dan concuslion drawing/verification atau penarikan kesimpulan.

\section{HASIL PENELITIAN DAN PEMBAHASAN}

\section{Desain Kurikulum Sekolah Islam Terpadu Insan Kamil Sidoarjo}

Desain kurikulum di SMPIT Insan Kamil Sdoarjo, menggunakan desain kurikulum yang telah menjadi ketetapan dari jaringan sekolah Islam Terpadu (JSIT), karena desain kurikulum sekolah Islam terpadu tidak dapat dipisahkan dari lingkaran kepengurusan jaringan sekolah Islam terpadu itu sendiri. Sekolah Islam terpadu merupakan sebuah lembaga pendidikan yang kedudukannya berada di bawah naungan dari JSIT (Jaringan Sekolah Islam Terpadu) Indonesia. 
Al-Tanzim : Jurnal Manajemen Pendidikan Islam E-ISSN: 2549-5720 P-ISSN: 2549-3663

Vol. 03 No. 02 (2019) : 49-60

https:/ / ejournal.unuja.ac.id/index.php/al-tanzim

Dalam JSIT terdapat beberapa tingkatan kepengurusan. Tingkatan kepengurusan tersebut terdiri dari pengurus daerah, pengurus wilayah, pengurus pusat dan dewan pembina. Pengurus daerah bertugas sebagai pelaksana kebijakan yang telah di tetapkan oleh pengurus wilayah dan pengurus pusat di tingkat kota atau kabupaten. Pengurus wilayah bertugas sebagai pelaksana kebijakan yang telah ditetapkan oleh pengurus pusat pada tingkat provinsi. Pengurus pusat sebagai pengurus tertinggi dalam organisasi JSIT Indonesia bertugas sebagai penanggungjawab terhadap organisasiorganisasi di bawahnya. Sedangkan dewan pembina bertugas sebagai pengarah, pendamping, penasehat pengurus pusat JSIT dalam menjaga nilainilai yang terkandung dalam visi dan misi JSIT Indonesia (Yusup, 2017).

Kurikulum dalam pengembangan Sekolah Islam Terpadu sangat berperan dalam penggambaran konsep keterpaduannya. Seluruh sekolah Islam terpadu yang tersebar di Indonesia telah memiliki kurikulum khas Sekolah Islam terpadu. Kurikulum pada sekolah Islam terpadu tersebut dinamakan dengan (kurikulum ke-Islam Terpadu-an), merupakan kurikulum yang telah dirumuskan oleh pengurus pusat JSIT lewat musyawarah nasional, dan telah disetujui oleh dewan pembina untuk kemudian diteruskan dan harus diterapkan oleh seluruh sekolah yang bergabung dalam jaringan sekolah Islam terpadu.

Kurikulum sekolah Islam terpadu berhasil membawa dampak yang cukup signifikan dalam proses pembelajaran yang berjalan di dalam kelas. Dampak ini biasa disebut dengan dampak Islamisasi kelas atau dampak Islamisasi pembelajaran. Disebut demikian karena kurikulum sekolah Islam terpadu telah mampu mengintegrasikan nilai-nilai Islam ke dalam berbagai mata pelajaran non pendidikan agama Islam. Bahkan indikator pencapain belajar siswa tidak hanya diukur dengan tercapainya sebuah kompetensi, akan tetapi ukuran yang lebih ditekankan adalah sejauh mana siswa dapat berkomitmen terhadap penjagaan nilai-nilai Islam yang telah mereka pelajari (Suyatno, 2015).

Gambaran tentang konsep kurikulum sekolah Islam terpadu di atas jelas berbeda dengan implementasi penyelenggaraan sekolah atau madrasah, apalagi sekolah negeri. Meskipun sekolah atau madrasah juga menggabungkan kurikulum umum dengan kurikulum agama, namun porsi yang digunakan sangatlah tidak seimbang, yaitu $70 \%$ pelajaran umum berbanding 30\% pelajaran agama, karena tujuan pendirian madrasah di Indonesia hanya sebatas menghilangkan kesenjangan antara pesantren yang menggambarkan jenis pendidikan tradisional dan sekolah sebagai jenis pendidikan yang modern. Namun integrasi mata pelajaran agama ke dalam mata pelajaran umum di madrasah hanya sebatas pada kurikulum secara tertulis saja, hanya sebagai formalitas administrasi lembaga dan tidak secara menyeluruh terhadap seluruh aspek dalam proses pendidikan (Al-Jazairi, 2009). 
SMPIT Insan kamil Sidoarjo telah membuat rumusan desain kurikulum dan rencana implementasi kurikulum tersebut dalam setiap kegiatan di sekolah, terutama kegiatan belajar mengajar di kelas. Dari hasil studi lewat dokumen kurikulum dan hasil dari wawancara bersama wakil kepala bagian kurikulum, didapatkan bahwasannya SMPIT Insan Kamil menggunakan kurikulum 2013 yang dipadukan dengan kurikulum Jaringan Sekolah Islam Terpadu (JSIT) dan kurikulum hasil olahan sekolah sendiri.

Data tersebut diperkuat oleh penuturan Kepala Sekolah SMPIT Insan Kamil, yang menyatakan bahwa kurikulum 2013 adalah kurikulum Negara. Dengan menggunakan kurikulum tersebut, maka sekolah ini bisa mengikuti ujian Nasional sebagaimana di sekolah-sekolah lain. Sedangkan kurikulum Jaringan Sekolah Islam Terpadu (JSIT) adalah kurikulum yang hanya dikhususkan untuk Sekolah Islam Terpadu di seluruh Indonesia. Di samping kedua kurikulum itu, SMPIT Insan Kamil juga memiliki kurikulum khusus yang diolah oleh sekolah sendiri.

Dari keterangan di atas, dapat dipahami bahwa kurikulum yang di pakai di SMP Islam Terpadu Insan Kamil Sidoarjo adalah kurikulum gabungan antara kurikulum nasional yaitu kurikulum 2013, kurikulum jaringan sekolah Islam terpadu dan kurikulum khas sekolah. Pola terpadu dalam proses pendidikan di SMP Islam Terpadu Insan Kamil Sidoarjo maksdunya adalah; perpaduan antar mata pelajaran umum dan keIslaman, dan perpaduan antara tiga kurikulum serta perpaduan kontrol siswa antara guru orang tua dan masyarakat.

Implementasi dari desain kurikulum yang diterapkan di SMP Islam Terpadu Insan Kamil Sidoarjo adalah sebuah desain kurikulum yang di susun dengan mengintegrasikan nilai-nilai Ke-Islaman pada semua mata pelajaran. Nilai-nilai keIslaman tersebut yang nantinya akan mempengaruhi karakter/akhlak peserta didik, terutama pada mata pelajaran pendidikan agama Islam.

Di SMP Islam Terpadu Insan Kamil Sidoarjo, pembelajaran pada mata pelajaran Pendidikan Agama Islam diorientasikan pada Pembinaan Akhlak yang sesuai dengan ajaran Al-Qur'an dan As-Sunnah. Konsep ini merupakan bentuk aplikasi dari perintah dalam agama Islam, di mana salah satu pokok ajarannya adalah tentang penyempurnan akhlak, bahkan diutusnya Rasulullah SAW adalah sebagai penyempurna nilai-nilai keluhuran sifat manusia (akhlak) tersebut. Hal ini sebagaimana diterangkan dalam sebuah hadist, bahwasanya Rasulullah SAW bersabda ; "Sesungguhnya aku diutus untuk menyempurnakan keluhuran akhlak" (Sholihah, 2017).

Gambaran secara singkat mengenai implementasi kurikulum di SMPIT Insan Kamil Sidoarjo, salah satu contohnya adalah dengan lebih menonjolkan bagaimana mengintegrasikan nilai-nilai ke-Islam bukan hanya di pelajaran PAI saja, tapi pada seluruh pelajaran. 
Al-Tanzim : Jurnal Manajemen Pendidikan Islam E-ISSN: 2549-5720 P-ISSN: 2549-3663

Vol. 03 No. 02 (2019) : 49-60

https:/ / ejournal.unuja.ac.id/index.php/al-tanzim

Selain tiga konsep kurikulum yang telah di jabarkan di atas, SMP Islam Terpadu Insan Kamil Sidoarjo juga telah membuat dan melaksanakan programprogam unggulan sesuai desain kurikulum sekolah Islam Terpadu, programprogam ini juga bermuara pada satu tujuan yaitu pembentukan akhlak siswa, program-progam tersebut di antaranya alah :

1. Tahfidz Al-Qur'an

SMP IT Insan Kamil Sidoarjo memiliki program unggulan yaitu para siswanya memiliki jaminan lulusan yaitu tahfidz Al-Qur'an minimal 5 juz. Selama belajar 3 tahun di SMP IT Insan Kamil Sidoarjo, siswa mendapatkan bimbingan setiap hari senin sampai kamis untuk dilakukan pembinaan tahfidz Al-Qur'an. Selain itu siswa juga dibiasakan untuk senantiasa tilawah maupun muroja'ah setiap hari, sehingga tidak ada satu haripun tanpa membaca Al-Qur'an bagi para siswa SMP IT Insan Kamil Sidoarjo.

2. Mentoring (Islamic Study Club)

Kegiatan mentoring (Islamic Study Club) merupakan kegiatan ekstrakulikuler SMP Islam Terpadu Insan Kamil yang berkenaan dengan pembentukan karakter dan akhlak Islami seluruh peserta didik. Kegiatan mentoring ini memiliki tujuan yaitu membangun kepribadian siswa agar memiliki aqidah yang bersih, ibadah yang benar, akhlak yang Islami, manajemen diri yang baik, manajemen waktu yang baik, fisik yang kuat dan sehat, pemahaman Islam yang syamil mutakamil, disiplin diri yang baik, kemampuan berkomunikasi yang baik, ukhuwah Islamiyah, tanggung jawab, kemandirian, empati, jujur, dan lain lain. Kegiatan mentoring dilaksanakan setiap hari jum'at dengan memberikan siswa bekal materi-materi tentang keagamaan. Kegiatan mentoring ini dibina oleh beberapa Murabby yang memantau para siswa melaluli buku monitor ibadah. Para siswa dibagi dalam beberapa kelompok dan berada dalam beberapa pembinaan Murabby.

3. Khitobah

Siswa dibiasakan untuk dapat menjadi pendakwah. Kegiatan khitobah dilakukan setelah selesai sholat berjama'ah yaitu setelah selesai sholat berjama'ah dhuhur serta Ashar. Khitobah juga dilakukan dalam dua bahasa yaitu bahasa Inggris serta bahasa Arab. Sehingga selain para siswa bisa belajar tentang materi-materi ajaran agama, siswa juga belajar untuk membiasakan berbicara dalam bahasa Inggris serta bahasa Arab.

4. Pembiasaan siswa berakhlak mulia

Kegiatan pembangunan karakter ini ada serta masuk di seluruh aktivitas yang terjadi di SMP Islam Terpadu Insan Kamil, bahkan ekstra kurikuler. Ketika ada sikap siswa yang tidak sesuai, misalnya tertawa secara berlebihan, maka guru wajib menegur, sehingga pembentukan karakter di sini pengawalannya dimulai dari hal kecil, bukan hanya pada hal yang besar-besar saja. Semua hal yang berkaitan dengan akhlak menjadi fokus perhatian. 
Kemudian ketika guru SMP IT Insan Kamil Sidoarjo menemukan penyimpangan di luar sekolah, maka akan dilakukan pembinaan lanjutan saat di sekolah. Pengawasan dan pembinaan karakter ini tidak hanya menjadi tugas guru PAI saja, tetapi seluruh guru memiliki kewajiban dalam membentuk akhlak peserta didik.

5. Home Visit

Program ini merupakan bentuk kegiatan yang melibatkan kerja sama antara para pengajar di sekolah dan wali murid atau orang tua. Bentuk kegiatannya adalah melakukan kunjungan ke rumah-rumah siswa untuk melakukan diskusi dengan orang tua mengenai perkembangan siswa, baik di sekolah maupun di rumah, dan juga mendiskusikan pemecahan masalah, jika memang terjadi masalah pada siswa.

6. Studi Banding Sekolah

Kegiatan studi banding ini merupakan kegiatan yang fokus utamanya adalah memberikan percontohan kepada guru dan siswa tentang karakter yang terbaik dalam lingkungan sekolah, yang dapat dilihat dari observasi di sekolah-sekolah unggul, baik di dalam maupun di luar negeri.

Dalam implementasi kurikulum melalui kegiatan di sekolah sebagaimana yang telah di bahas di atas, di SMPIT Insan Kamil Sidoarjo juga memberikan penekanan lebih kepada guru-gurunya dalam memberikan contoh yang terbaik bagi siswa. SMP Islam Terpadu Insan Kamil Sidoarjo membuat program khusus bagi guru-gurunya. Program ini bukan hanya sebagai sarana penguat dari segi ilmu pengetahuan, akan tetapi para guru juga dikuatkan secara ruhiyyah yakni dengan diadakannya halaqoh setiap satu minggu sekali, yang di dalamnya membahas tentang ajaran-ajaran agama, tentang akhlak dan lain sebagainya. Melalui hal tersebut, diharapkan guru bukan hanya memberikan ilmu pengetahuan saja kepada siswa, akan tetapi juga memberikan pemahaman agama yang sesuai dengan Al-Qur'an dan Sunnah.

Selain program halaqoh, para guru juga belajar dari segi kepemimpinan yakni dengan diadakannya LDKG (Latihan Dasar Kepemimpinan Guru) yang diadakan setiap satu tahun sekali. Program-progam di atas bertujuan untuk membentuk pendidik yang akan menjadi percontohan bagi peserta didiknya dalam berakhlak yang baik pada segala aktivitas yang di kerjakannya.

\section{KESIMPULAN}

Desain Kurikulum pada sekolah Islam terpadu merupakan desain yang telah dirumuskan dan ditetapkan oleh pengurus pusat dari Jaringan sekolah Islam terpadu (JSIT), sesuai dengan tujuan yang telah dirancang dan disepakati bersama, dan wajib diikuti oleh seluruh anggota jaringan sekolah Islam terpadu. 
Al-Tanzim : Jurnal Manajemen Pendidikan Islam

E-ISSN: 2549-5720 P-ISSN: 2549-3663

Vol. 03 No. 02 (2019) : 49-60 https:// ejoumal.unija.ac.id/ index.php/al-tanzim

Sekolah Islam terpadu telah mendesain sebuah kurikulum yang mampu mengintegrasikan nilai-nilai Islam ke dalam berbagai mata pelajaran non pendidikan agama Islam, bahkan indikator pencapaian belajar siswa tidak hanya diukur dengan tercapainya sebuah kompetensi, akan tetapi ukuran yang lebih ditekankan adalah, sejauh mana siswa dapat berkomitmen terhadap penjagaan nilai-nilai Islam yang telah mereka pelajar. Sedangkan bentuk implementasi dari pelaksanaan terhadap desain kurikulum di SMPT Insan kamil adalah dengan menggunakan kurikulum 2013 yang dipadukan dengan kurikulum Jaringan Sekolah Islam Terpadu (JSIT) dan kurikulum hasil olahan sekolah sendiri.

Desain kurikulum yang diterapkan di SMP Islam Terpadu Insan Kamil Sidoarjo adalah sebuah desain kurikulum yang disusun dengan mengintegrasikan Nilai-nilai Ke-Islaman pada semua mata pelajaran. Nilai-nilai keIslaman tersebut yang nantinya akan mempengaruhi karakter/akhlak peserta didik. 


\section{DAFTAR PUSTAKA}

Afrizal. (2011). Sistem Manajemen Sekolah Islam Terpadu Menuju Sekolah Standart Nasional di Kota Dumai. Universitas Islam Negeri Sultan Syarif Kasim Riau.

Al-Jazairi, A. B. J. (2009). Minhajul Muslim. Al-Madinah Al-Munawwaroh: Maktabah Ulum Wal Hikmah.

Cullinan, M. (2016). Application to The UAE Context. International Journal of Curriculum and Instruction, 8(1), 54-68. https://doi.org/10.1175/JCLI-D12-00759.1

Fatkuroji, F. (2012). Kebijakan Pembelajaran Terpadu dalam Meningkatkan Minat Konsumen Pendidikan. Nadwa: Jurnal Pendidikan Islam, 6(2), 249268. https:/ / doi.org/10.21580/nw.2012.6.2.591

Hanun Asrohah, A. A. A. (2013). Pengembangan Kurikulum. Surabaya: Kopertais IV Press.

JSIT, T. (2006). Sekolah Islam Terpadu Konsep dan Aplikasi. Bandung: Syamil Cipta Media.

Offorma, G. C. (2016). Integrating Components of Culture in Curriculum Planning. International Journal of Curriculum and Instruction, 8(1), 1-8.

R. Syarifudin. (2004, April). Memberdayakan Sekolah-sekolah Islam. Republika.

Sholihah. (2017). Desain Pengembangan Kurikulum Pendidikan Agama Islam. KUTTAB, 1(2), 168-179.

Sugiyono. (2010). Metodologi Penelitian Pendidikan. Bandung: Alfabeta.

Suparno. (2018). Analisis Faktor-Faktor Pembentuk Karakter Smart Siswa di Sekolah Islam Terpadu. Jurnal Pendidikan Karakter, 8(1), 62-73.

Susanto, A. (2010). Pemikiran Pendidikan Islam. Jakarta: Amzah.

Suyatno, S. (2013). Sekolah Islam Terpadu; Filsafat, Ideologi dan Tren Baru Pendidikan Islam di Indonesia. Jurnal Pendidikan Islam, 2(2), 355. https:/ / doi.org/10.14421/jpi.2013.22.355-377

Suyatno, S. (2015). Sekolah Islam Terpadu dalam Peta Sistem Pendidikan Nasional. Al-Qalam, 21(1), 1-10. https:/ / doi.org/10.32678/alqalam.v32i2.553

Tajab, M. (2014). Sintesa Atas Dikotomi Pendidikan Islam. At-Tajdid: Jurnal Ilmu Tarbiyah, 3(2), 21-36.

Usman, M. U. (2008). Menjadi Guru yang Profesioanal. Bandung: Remaja Rosdakarya.

Yusup, M. (2017). Eksklusivisme Beragama Jaringan Sekolah Islam Terpadu (JSIT) Yogyakarta. Religi: Jurnal Studi Agama-Agama, 13(1), 75-96. https:/ / doi.org/10.1017/CBO9781107415324.004 